\title{
Heterogeneity in tall fescue pastures created and sustained by cattle grazing
}

\author{
MARIA SILVIA CID, AND MIGUEL A. BRIZUELA
}

Cid and Brizuela are professors, Facultad de Ciencius Agrarias, Universidad Nacional de Mar del Plata (UNMdP)(7620) Balcarce, Argentina; Cid is research scientist, Consejo Nacional de Investigaciones Cientificas y Técnicas (CONICET) de Argentina; Brizuela is research scientist, Comisión de Investigaciones Cientificas (CIC) de la Provincia de Buenos Aires, Argentina.

\begin{abstract}
In continuous grazing systems the amount of herbage and its quality is a matter of primary concern. However, at moderate stocking, cattle grazing usually leads to the generation of patches differing in forage quality and quantity even in virtually monospecific pastures. This patchiness influences subsequent vegetation and animal responses. We analyzed the heterogeneity created and sustained by cattle grazing in a tall fescue (Festuca arundinacea Schreb.) pasture at stocking densities ranging from 1.8 to 4.1 animals ha-1 over 2 years. Cattle grazing created and maintained a mosaic of areas with different degrees of utilization. Heavily utilized patches had less biomass per unit surface, but their live biomass was more dense and had a higher nitrogen concentration. Patch boundaries fluctuated throughout the year at all stocking densities. Patch locations were more stable at the lower stocking densities, where cattle repeatedly returned to heavily utilized patches even though they represented less than $30 \%$ of the total surface. This reinforces the idea that, at low and moderate stocking densities, cattle can obtain a nutritional benefit by patch grazing. The percentage of heavily utilized patches reached a maximum value at an instantaneous grazing pressure of approximately 0.0016 animal units $\mathrm{kg}$ forage $\mathrm{e}^{-1}$. When this threshold is passed, animal selection between patches could be conditioned by the presence of feces or thistles, and pasture condition affected by overgrazing of the heavily utilized patches.
\end{abstract}

Key Words: patch grazing, Festuca arundinacea Schreb., Argentina

Cattle graze selectively even in virtually monospecific pastures creating vegetation mosaics in which heavily utilized patches alternate with others that are lightly grazed (Gibb and Ridout 1986, Illius et al. 1987). The regrowth of the heavily utilized areas is more digestible than that of the surrounding vegetation suggesting a nutritional facilitation (McNaughton 1984, lllius et al. 1987). As a result, patches with different biomass quantity and quality coexist in the same paddock and this drives the subsequent use of patches.

The authors are grateful to Gabriela Cendoya (UNMdP) for assistance in statistical analysis, and to Dr. Osvaldo E. Sala (Universidad de Buenos Aires) and 2 anonymous reviewers for valuable suggestions. This work was supported by $\mathrm{CON}$ ICET, UNMdP and EEA INTA Balcarce, Argentina.

Manuscript accepted 2 Jan. 1998.

\section{Resumen}

En sistemas de pastoreo continuo, la cantidad y la calidad del forraje son aspectos básicos a considerar. Sin embargo, a cargas moderadas y aún en pasturas virtualmente monoespecíficas, el pastoreo de bovinos determina la generación de áreas que difieren en calidad y en cantidad de forraje. Esta heterogeneidad en la vegetación influencia su uso posterior y la respuesta animal. Nosotros analizamos durante dos años la heterogeneidad creada y mantenida por el pastoreo de vacunos en una pastura de festuca alta (Festuca arundinacea Schreb.) en un rango de densidades de carga de 1.8 a 4.1 animales ha $^{-1}$. El pastoreo de vacunos creó y mantuvo un mosaico de áreas con diferente nivel de utilización. Las áreas intensamente utilizadas tuvieron menos biomasa por unidad de superficie, pero su biomasa viva fue más densa y con mayor concentración de nitrógeno. Los bordes de las áreas fluctuaron a través del año en todas las densidades de carga. La ubicación de las áreas fue más estable a las menores densidades de carga, ya que los animales retornaron repetidamente a las áreas intensamente utilizadas aún cuando ellas representaban menos del $30 \%$ del total de la superficie. Esto refuerza la idea de que, a bajas y moderadas densidades de carga, los vacunos pueden obtener un beneficio nutricional pastoreando en manchones. El porcentaje de áreas intensamente utilizadas alcanzó un máximo a una presión de pastoreo instantánea de aproximadamente $\mathbf{0 . 0 0 1 6}$ unidades animales $\mathrm{kg}_{\text {forraje }}{ }^{-1}$. En la proximidad de este valor, la selección animal entre áreas podría estar condicionada por la presencia de heces o cardos; más allá de este umbral, la condición de la pastura podría verse afectada por sobrepastoreo de las áreas intensamente utilizadas.

Generation and maintenance of the vegetation mosaic depend upon the relationship between herbivore intake and pasture growth rates (Shiyomi et al. 1983). The relative proportions of patches with different utilization levels change according to season, grazing system and stocking density.

In Argentina, perennial temperate pastures are used with varying grazing systems and stocking densities according to production goals (Cascardo et al. 1991). In these pastures, patch grazing under continuous grazing in moderate stocked systems is frequently recognized although it has not been evaluated. In addition, the effect of different stocking densities upon the heterogeneity of the herbage available has not been considered. The purposes of this work were: (1) to determine whether cattle graz- 
ing generates patchiness in Festuca arundinacea pastures stocked at different rates, (2) to assess the effect of stocking density on patchiness, (3) to compare the structure and the nitrogen concentration of the induced patches, and (4) to monitor seasonal and annual changes in patch locations.

\section{Materials and Methods}

The study was conducted in the south east of the Buenos Aires province, Argentina $\left(37^{\circ} 45^{\prime} \mathrm{S}, 58^{\circ} 18^{\prime} \mathrm{W} ; 130 \mathrm{~m}\right.$ above sea level) during 1987 and 1988 in a 12 ha pasture dominated by Festuca arundinacea Schreb., and with Dactylis glomerata L. and Paspalum dilatatum Poir. as the most important minor components. Mean annual temperature and rainfall in the region are $13.7^{\circ} \mathrm{C}$ and $900 \mathrm{~mm}$, respectively. Annual precipitation (959 and $859 \mathrm{~mm}$ in 1987 and 1988, respectively), as well as the amounts registered in the experimental period, were similar to the longterm median. The pasture had been under continuous grazing at 4 stocking densities from March to December since 1983 (Mezzadra et al. 1992). It was divided by electric fences into 8 small paddocks of variable area according to the corresponding stocking density. Each year, at mid summer, the pasture was mechanically cut to a uniform canopy height. The paddocks were grazed by Aberdeen Angus steers (8 months of age and weighing $200 \mathrm{~kg}$ in March) from early March to late December at 4 stocking densities and 2 replicates. Stocking densities were 2.3, 2.9, 3.5, and 4.1 animals per ha in 1987 and 1.8, 2.3, 2.8, and 3.3 animals per ha in 1988. All the treatments were implemented with the same number of animals each year ( 5 and 4 in 1987 and 1988, respectively).

Vegetation was sampled in September and December each year. Vegetation height and area of patches showing different degrees of utilization were estimated along $320 \mathrm{~m}$ transects in each paddock at each sampling date. Areas with nearly all available forage consumed and signs of recent defoliation were con- sidered as heavily utilized patches. On the contrary those ungrazed or with signs of light defoliation were considered as lightly utilized patches (Ring et al. 1985).

The relative percentage of each type of patch was estimated from its length along the transects (Illius et al. 1987). To determine whether the percentage of heavily utilized patches was independent of year and sampling date, it was related to instantaneous grazing pressure, expressed as animal units $\mathrm{kg}$ forage $^{-1}$ (Forage and Grazing Terminology Committee 1992). Animal live weights for 1987 and 1988 were obtained from Mezzadra et al. 1992 and Mezzadra (unpublished data), who weighed the animals every 14 days from May to January both years.

Total aboveground biomass within each patch type was estimated by clipping ten $0.1 \mathrm{~m}^{2}$ frames in each paddock. Plots were randomly located within patch type. Total biomass was sorted into live and dead components; live biomass was later separated in grasses, legumes, and forbs. Samples were oven-dried at $60^{\circ} \mathrm{C}$ and weighed. We estimated total and live biomass density (g DM $\mathrm{m}^{-2} \mathrm{~cm}^{-1}$ ) from biomass and plant height. Nitrogen concentration in live biomass was determined from 3 samples per paddock by the micro-Kjeldahl procedure (AOAC 1965). Total forage availability in each treatment was computed from the percentage of each patch type and its biomass.

Data were statistically analyzed with a split-split plot in space and time design, with stocking density as plot and patch type as sub-plot. The three-way interactions were not significant $(p>0.1)$ and were pooled with the residual error term. Vegetation responses to the different stocking densities were analyzed using orthogonal polynomials for significant linear and quadratic responses (Steele and Torrie 1980). Because different stocking densities were used in 1987 and 1988, data from each year were analyzed separately.

Seasonal and annual variation in patch location werc monitored over three $2 \times 3 \mathrm{~m}$ permanent areas per paddock, randomly located. At each sampling date heavily and lightly utilized patches were delimited with plastic strips and photographed from a height

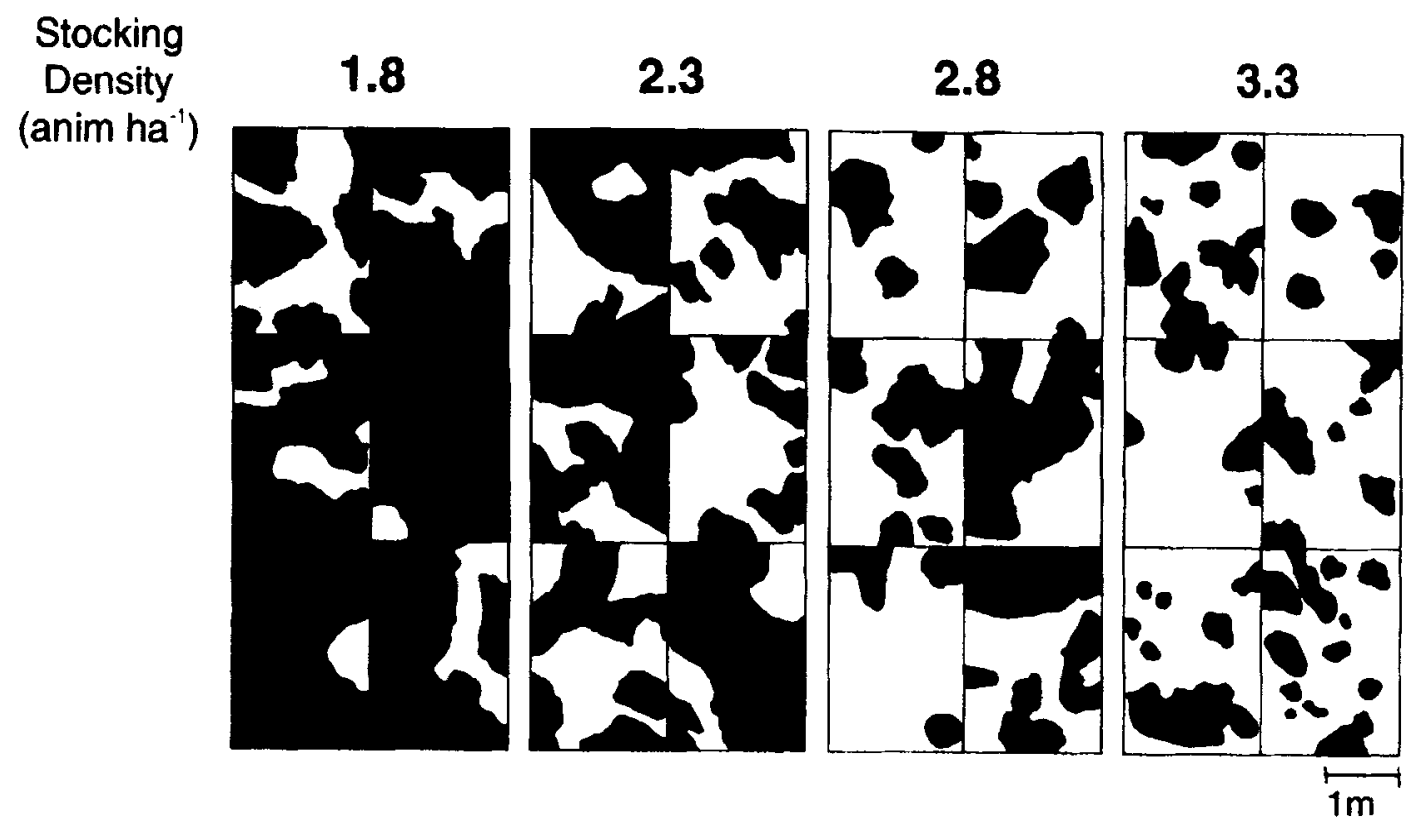

Fig. 1. Heavily and lightly utilized patches in six $3 \times 2$ m quadrats in tall fescue padducks continuously grazed by cattle at 4 stocking densities. Balcarce, Argentina, December of 1988 . Black = lightly utilized patches, white = heavily utilized patches. 
PATChutilization: LIOHT SEP. - MEAvY SEP. - - DEC. - D DEC. - -

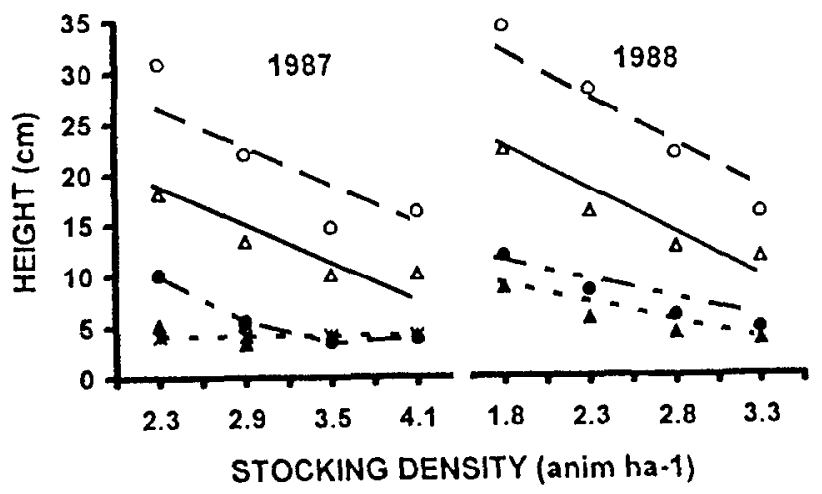

Fig. 2. Height of heavily and lightly utilized patches in a tall fescue pasture continuously grazed by cattle at different stocking densities. Balcarce, Argentina, September and December, 1987-88.

of $3 \mathrm{~m}$. Maps of the pasture heterogeneity were obtained from the pictures and compared to determine changes in patch position within and between years. Stable and unstable (heavily utilized patches $\rightarrow$ lightly utilized patches, lightly utilized patches $\rightarrow$ heavily utilized patches) areas were determined by the overlap of 360 points systcmatically located over each replicate map (Bakker et al. 1983, Willms et al. 1988). Mosaic fixation was quantified by the Kappa index (Fleiss 1981). The Kappa index is an estimator of the area that remains without change beyond the amount expected by chance alone. A Kappa index $=1$ indicates complete agreement in overlap and therefore perfect stability, while a Kappa index between 0 and 1 values indicates more than chance agreement, and different degrees of stability. A Kappa index $\leq 0$ indicates instability. The $z$ value $\left(z=K a p p a / S E_{(K a p p a)}\right)$ for each comparison was used to determine the statistical significance of Kappa index. As Kappa values are normally distributed we compared them by a test of normal mean differences. We used a global significance level of 0.05 that was adapted to each comparison by the total number of mean compared according to Bonferroni criteria (Miller 1966).

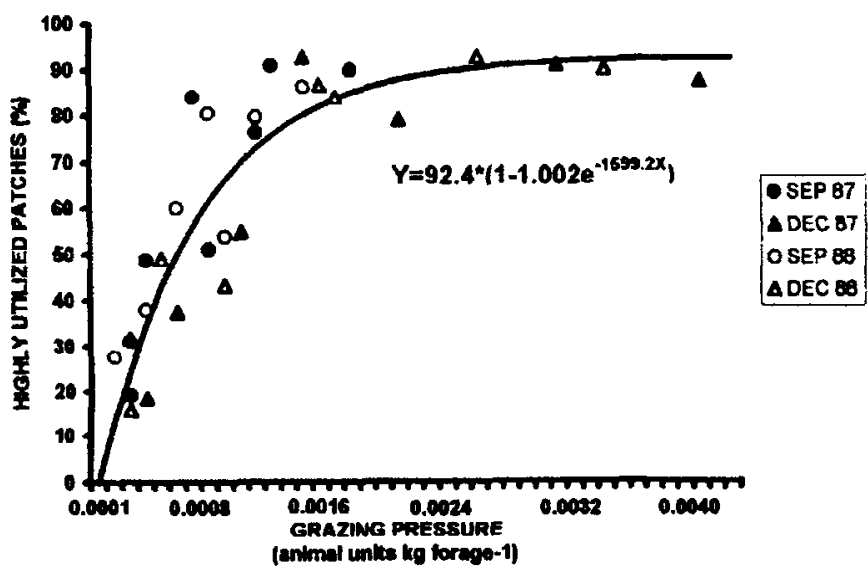

Fig. 3. Relationship between instantaneous grazing pressure and percentage of heavily utilized patches in a tall fescue pasture continuously grazed by cattle. Balcarce, Argentina, September and December, 1987-88.

\section{Results}

Canopy height of heavily utilized patches was less than that of lightly utilized patches $(p<0.05)$ under all stocking densities in both years, indicating that cattle grazing created and sustained pasture structural heterogeneity through a broad stocking density gradient (Fig. 1). The increase in canopy height from September to December, averaged over stocking densities, was higher in lightly utilized patches. While the average seasonal increase in lightly utilized patches was around $8 \mathrm{~cm}$ it was only $2 \mathrm{~cm}$ in heavily utilized patches. The response of height to increasing stocking density differed between patches. The decrease in height of lightly utilized patches with increasing stocking density was linear (Fig. 2). In September 1987, the height of the heavily utilized patches was not affected by stocking density, remaining stable at $4.5 \mathrm{~cm}$. In December the response was quadratic and height exceeded 5 $\mathrm{cm}$ only at the lowest stocking density. In 1988 height decreased linearly in the heavily utilized patches and at a lower rate than in the lightly utilized patches. The average percentage of heavily utilized patches increased $(\mathrm{p}<0.01)$ as stocking density increased, varying from 19.0 to $90.3 \%$ and from 21.5 to $82.9 \%$ in 1987 and
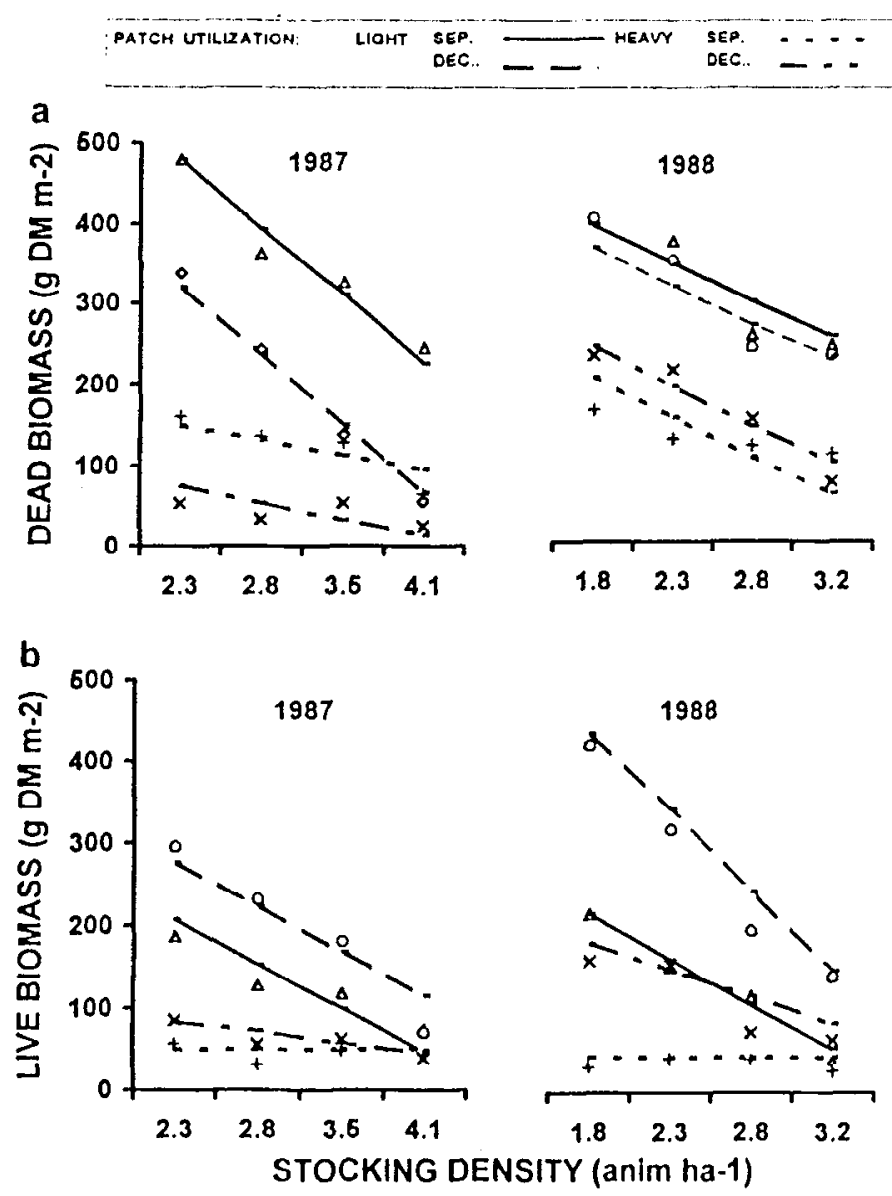

Fig. 4. Dead (a), and live (b) biomass ( $\left(\mathrm{DM} \mathrm{m}^{-2}\right.$ ) in heavily and lightly utilized patches in a tall fescue pasture continuously grazed by cattle at different stocking densities. Balcarce, Argentina, September and December, 1987-88. 


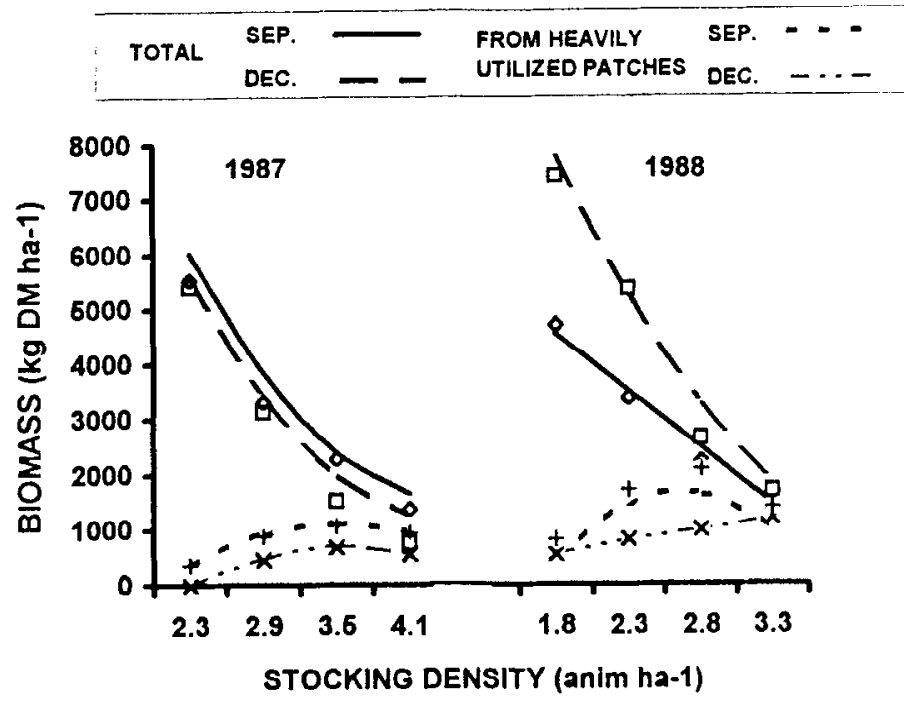

Fig. 5. Total biomass and biomass coming from heavily utilized patches in a tall fescue pasture at different stocking densities. Total biomass was computed from the percentage of surface of heavily and lightly utilized patches, and their biomass by unit surface. Balcarce, 1987-1988.

1988, respectively (Fig. 1). The area of heavily utilized patches stabilized when the instantaneous grazing pressure reached 0.0016 animal units $\mathrm{kg}$ forage ${ }^{-1}$, independent of date and year (\% heavily utilized patches $\left.=92.4 *\left(1-1.002 \mathrm{e}^{-1599.2 \mathrm{x}}\right) ; \mathrm{p}<0.001, \mathrm{r}^{2}=0.83\right)$ (Fig. 3).

As expected, heavily utilized patches had less $(\mathrm{p}<0.05)$ total, live and dead biomass in both years; however in 1987 they had higher live biomass percentage ( 31 vs $26 \%$; $=0.065$ ). In 1987 , dead biomass declined linearly as stocking density increased. The rate of decline was higher in lightly utilized patches (Fig. 4a). On the contrary, increasing stocking density reduced dead biomass at the same rate in both types of patches in 1988. In September of both years, the live biomass of heavily utilized patches was similar at all stocking densities, remaining around $50 \mathrm{~g} \mathrm{~m}^{-2}$. In December the decline of live biomass as stocking density increased was lower than that of the lightly utilized patches (Fig. 4b).

Legumes and other dicotyledons were minor components of the vegetation, never representing more than $20 \mathrm{~g} \mathrm{DM} \mathrm{m}^{-2}$. Heavily utilized patches had higher legume biomass in 1988 (1987: 0.3 vs 0.1 ; 1988: 9 vs $2 \mathrm{~g} \mathrm{DM} \mathrm{m}^{-2} ; \mathrm{p}<0.05$ ). Biomass of other dicotyledons was higher in heavily utilized patches in 1987 (1987: 4 vs 1; 1988: 5 vs $6 \mathrm{~g} \mathrm{DM} \mathrm{m}^{-2} ; \mathrm{p}<0.01$ ) when overall stocking densities were higher.

As stocking density increased, a greater amount of the forage available came from the heavily utilized patches (Fig. 5). This was a result of the differences between patches in biomass per unit surface (Fig . 4a,b), and in surface percentage per paddocks (Figs. 1 and 3).

Stocking density affected neither live biomass nitrogen concentration nor biomass density. Live biomass nitrogen concentration differed between patches and dates in both years. It was $26 \%$ higher in the heavily utilized patches than in the lightly utilized patches ( $p<0.01$; Fig. 6a) and decreased around 35\% from September $(1987=2.8,1988=2.4 \%)$ to December $(1987=1.8$ and $1988=1.6 \% ; \mathrm{p}<0.01)$. Average total biomass density did

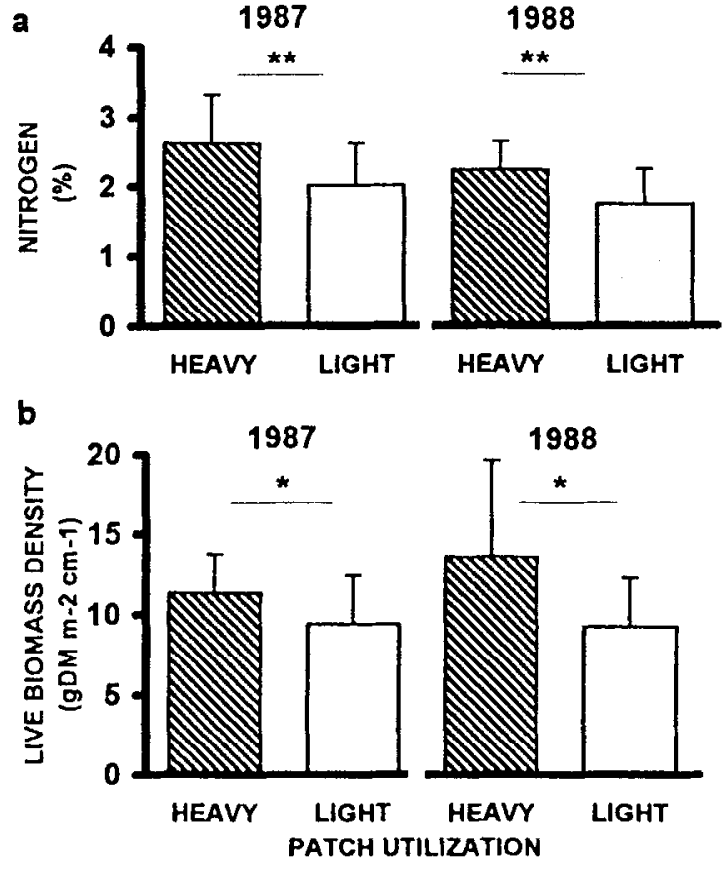

Fig. 6. Average live biomass nitrogen percentage (a) and density (b) in heavily and lightly utilized patches in a tall fescue pasture continuously grazed by cattle at different stocking densities. Balcarce, Argentina. 1987-88.

not differ between patches in 1987 (heavily utilized patches 30.7 \pm 15.6 vs lightly utilized patches $27.9 \pm 13.2 \%$; $>>0.05$ ), but in 1988 it was $43 \%$ higher in heavily utilized patches $(35.4 \pm 9.0$ vs $24.8 \pm 6.3 \% ; \mathrm{p}<0.05$ ). Furthermore, in both years live biomass density was higher in heavily utilized patches (Fig. 6b).

Patch location changed from 1 year to the next (Kappa values $\leq 0$ ) but was fixed to some degree within each year (Table 1). Patch location was more stable at the lower stocking density; around $45 \%$ of the heavily utilized patches recorded in September remained without change until December. At the highest stocking densities, although $80 \%$ of the heavily utilized patches did not change loca-

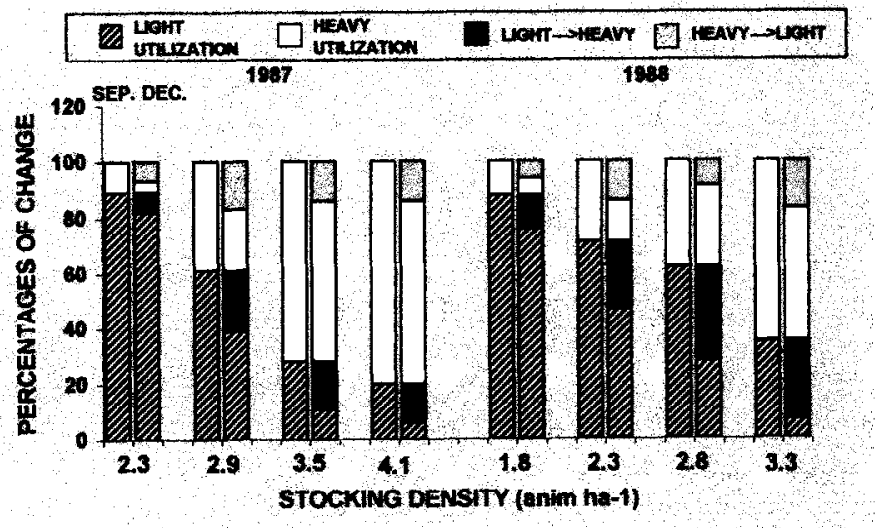

Fig. 7. Changes in percentages of heavily and lightly utilized patches from September to December in a tall fescue pasture continuously grazed by cattle at different stocking densities. Balcarce, Argentina. 1987-88. 
Table 1. Seasonal (a) and annual (b) stability of the vegetation mosaic of patches with different degree of utilization in a tall feseue pasture grazed by cattle at different stocking densities. Balcarce, Argentina, 1987-1988.

\begin{tabular}{|c|c|c|c|c|c|c|c|c|}
\hline \multirow{2}{*}{$\begin{array}{l}\text { (a) Seasonal } \\
\text { (Sep. to Dec.) } \\
\text { Paddock (\#) }\end{array}$} & \multicolumn{4}{|c|}{1987} & \multicolumn{4}{|c|}{1988} \\
\hline & 1 & 2 & 3 & 4 & 1 & 2 & 3 & 4 \\
\hline $\begin{array}{l}\text { Stocking density } \\
\text { (anim ha-1) }\end{array}$ & 2.3 & 2.9 & 3.5 & 4.1 & 1.8 & 2.3 & 2.8 & 3.2 \\
\hline Kappa index & $0.33^{* * a}$ & $0.21 * * b$ & $0.21 * * b$ & $0.11^{* * c} \mathrm{c}$ & $0.26 * * a$ & $0.16^{* * b}$ & $0.19 * * b$ & $-0.07^{* *} \mathrm{c}$ \\
\hline $\mathrm{SE}$ & 0.008 & 0.013 & 0.013 & 0.011 & 0.010 & 0.013 & 0.013 & 0.013 \\
\hline
\end{tabular}

(b) Annuals

(Dec. 87 to Dec. 88 )

\begin{tabular}{lcccc} 
Paddock (\#) & 1 & 2 & 3 & 4 \\
\cline { 2 - 5 } Kappa index & $-0.01 \mathrm{~b}$ & $-0.11^{++} \mathrm{a}$ & $-0.05^{++b}$ & $-0.04^{++b}$ \\
SE & 0.011 & 0.013 & 0.013 & 0.012
\end{tabular}

The spatial distribution of differently utilized patches is stable $\left(^{* *}, \mathrm{p}<0.01\right)$ or unstable $\left(^{++}, \mathrm{p}<0.01\right)$.

For each year Kappa values with different letters differ $(\mathrm{p}<0.05)$.

tion, only $28 \%$ of the lightly utilized patches remained stable (Fig. 7). The percentage fixed beyond chance changed from 33 to $-7 \%$ according to stocking density and year, and was always higher at low stocking densities. Stability of pasture at the same stocking density was higher in 1987 than in 1988 (Table 1).

\section{Discussion}

In pastures dominated by tall fescue continuously grazed, cattle used the forage unevenly over a broad range of stocking densities. Calle grazing created a mosaic of patches with different levels of utilization. Live biomass of highly utilized patches had higher nitrogen concentration and density than that of lightly utilized patches. This agrees with findings of previous studies that showed higher density and digestibility of biomass in shorter patches in ryegrass pastures heavily stocked during short grazing periods (Illius et al. 1987).

At the paddock level, patchiness occurs as result of selective grazing caused by forage differences between microsites (Bakker et al. 1983); once patches have been formed they may govern the grazing pattern. Later, the regrowth of highly utilized patches is preferred over the more mature vegetation (Shiyomi et al. 1983, Willms et al. 1988). In our study, as stocking density increased, the percentage of surface occupied by highly utilized patches and their degree of utilization also increased. However, the percentage of highly utilized patches reached a maximum value at a grazing pressure of approximately 0.0016 animal units per $\mathrm{kg}$ forage biomass. When this value is reached, selection between patches seems to be related to the presence or absence of feces or thistle plants in lightly utilized patches. Beyond that value, animal gains and pasture condition could be affected by overgrazing of heavily utilized patches. Stocking density principally affected the height of lightly utilized patches, while the highly utilized patches remained fairly constant at a height of approximately 5 $\mathrm{cm}$. Thus, most of the structural differences due to stocking density were the relative proportion of both types of patches and the height of the lightly utilized patches. Gibb and Ridout (1986) found a similar stocking density effect on Lolium perenne $\mathrm{L}$. and Trifolium repens L. pastures maintained at mean heights of 3 and
$7 \mathrm{~cm}$ by cattle grazing. After the first month of grazing the mean height of the frequently grazed patches reached a fairly constant value of approximately $3 \mathrm{~cm}$ on both swards.

Heavily utilized patches were shorter and had less total and live hiomass, but they had higher nitrogen concentration and were more dense. Higher nitrogen concentration in heavily utilized patches may result from a combination of causes. Concentrated grazing maintains vegetation in a shorter and more juvenile stage (Hodgson et al. 1994), and younger leaves have lower C: $\mathrm{N}$ ratios (Jameson 1964, Kamstra et al. 1968). In addition, defoliation may increase nitrogen uptake and allocation of nitrogen to leaves (Reuss et al. 1983, Jaramillo and Detling 1988, Polley and Detling 1988).

In virtually monospecific swards, where factors such as taste, palatability, and nitrogen content are highly correlated with digestibility, the main influence on preference is likely to be the potential rate of herbage intake (Illius et al. 1987). Cattle prefer to graze repeatedly in heavily utilized patches if their height does not constrain the rate of intake or if the animals compensate bite size reduction by increasing biting rate. At the lowest stocking densities cattle repeatedly used the highly utilized patches. Although they represented less than $30 \%$ of the paddocks in September, around $40 \%$ of this area remained in the same location in December, a value that exceed that expected by chance alone. At high stocking densities, where the vegetation mosaic was unstable or only slightly stable, patchiness could be the result of animals avoidance of forage near feces (Jones and Ratcliff 1983, Haynes and Williams 1993) or thistles (Oswald 1985, Brizuela and Cid 1991). Cattle refuse the forage near feces for a short period of time but thereafter prefer it because of its higher biomass availability. Thus, a high proportion of the highly utilized patches would change their location in a short time, resulting in lower stability.

If cattle grazing maintains patches of dense and nutritious forage and animals are able to compensate for possible constraints imposed by height to their rate of intake, similar individual animal gains should be expected under grazing pressure lower than 0.0016 animal units $\mathrm{kg}$ forage ${ }^{-1}$. Mean daily gains from September to December for 1987 (Mezzadra et al. 1992), and 1988 (Mezzadra unpublished data) support this idea. In spite of 
large differences in forage availability between treatments, mean individual gains did not differ $(p>0.05)$ as stocking density increased in $1987\left(0.540,0.521,0.530,0.415 \mathrm{~kg}_{\text {animal }}{ }^{-1}\right.$ day $\left.^{-1}\right)$ and in $1988\left(0.491,0.483,0.553\right.$ and $0.438 \mathrm{~kg}_{\text {animal }}^{-1}$ day $\left.^{-1}\right)$. The lowest absolute value at the highest stocking density in 1987 could be related to a limitation imposed on the animals in December, when grazing pressure was higher than 0.0016 , and forage availability was below $1,000 \mathrm{~kg} \mathrm{DM} \mathrm{ha}^{-1}$. At this point a critical stocking rate (Hart 1978) could be exceeded and individual animal performance would decline. However, in the southeast of Buenos Aires province, pastures based on fescue are usually rested between December and February. Thus, the occasional shortage of fescue pasture availability in December has no major impact upon cattle gains because cattle are usually allocated to warm season pastures based on alfalfa or red clover with higher quality. The conceptual model of the effects of stocking rate on livestock production remains continually under revision (Heitschmidt and Taylor 1991). The patch grazing approach is useful for explaining similar weight gains at less than the critical stocking rate. However, because the effects of different grazing systems on livestuck production vary widely over time and space, possible interactions of seasonality (Hart 1978) and grazing system (Heitschmidt and Taylor 1991) should be considered.

Our results suggest that patch grazing is nutritionally beneficial for cattle. However, when a grazing pressure threshold is passed, animal selection between patches could be conditioned by the presence of feces or thistles, animal gain reduced, and pasture condition affected by overgrazing of the heavily utilized patches.

\section{Literature Cited}

AOAC. 1965. Official methods of analysis, 10th ed. Assoc. of Official Agr. Chem., Washington D.C.

Bakker, J.P., J. de Leeuw, and S.E. van Wieren. 1983. Micro-pattern in grassland vegetation created and sustained by sheep grazing. Vegetatio 55:153-151.

Brizuela M.A. and M.S. Cid. 1991. Enmalezamiento con cardos de una pastura de festuca alta (Festuca arundinacea Screb.) en relación a la carga animal. Rev. Argentina Prod. Anim. Vol. 11:129-134.

Cascardo, A.R., J.B. Pizarro, M.A. Peretti, and P.O.Gómez. 1991. Sistemas de producción predominantes. p. 95-146. In: O. Barsky (ed.), El desarrollo agropecuario pampeano. INDEC, INTA, IICA., Argentina.

Fleiss, J.L. 1981. Statistical methods for rates and proportions. 2nd ed. John Willey and Sons, Inc. Toronto.

Forage and Grazing Terminology Committee. 1992. Terminology for grazing lands and grazing animals. J. Prod. Agr. 5:191-202.

Gibb, M.J. and M.S. Ridout. 1986. The fitting of frequency distributions to height measurements on grazed swards. Grass and Forage Sci. 41:247-249.

Hart, R.H. 1978. Stocking rate theory and its application to grazing on rangelands. p. 547-550. In: D.N. Hyder (ed.). Proc. First Int. Rangeland Congr. Soc. Range Manage., Denver, Colo.

Haynes, R.J. and P.H. Williams. 1993. Nutrient cycling and soil fertility in the grazed pasture ecosystem. Advan. in Agr. 49:119-199.

Heitschmidt, R.K. and C.A. Taylor. 1991. Livestock production. p. 161-177. In: R.K. Heitschmidl and J.W. Stuth (eds.). Grazing Management. An ecological perspective. Timber Press Inc., Porland, Ore.

Hodgson, J., D.A. Clark, and R.J. Mitchell. 1994. Foraging behavior in grazing animals and its impact on plant communities, p. 796-825. In: G.C. Fahey, Jr. (ed.), Forage quality evaluation, and utilization. Amer. Soc. of Agron., Crop Sci. Society. of America, Soil Sci. Soc. of America, Madison, Wisc.
Illius, W., D.G.M. Wood-Gush, and J.C. Eddison. 1987. A study of the foraging behaviour of cattle grazing a patchy sward. Biol. of Behav. 12:33-44.

Jameson, D.A. 1964. Effect of defoliation on forage plant physiology, p. 67-80. In: Forage Plant Physiology and Soil Range relationships. Amer. Soc. of Agron. Spec. Pub. 5.

Jaramillo, V.J. and J.K. Detling. 1988. Grazing history, defoliation and competition: effects on shortgrass production and nitrogen accumulation. Ecol. 69:1599-1608.

Jones, R.M. and D. Ratcliff. 1983. Patchy grazing and its relation to deposition of cattle dung pats in pastures in costal subtropical Queensland. J. Australian Inst. Agr. Sci. 49:109-111.

Kamstra, L.D., D.L. Schentzel, J.K. Lewis, and R.L. Elderkin. 1968. Maturity studies with western wheatgrass. J. Range Manage. 26:289-291.

MeNaughton, S.J. 1984. Grazing Lawns: on domesticated and wild animals. Amer. Nat. 128:937-939.

Mezzadra, C.J., J. Escuder, and M.C. Miquel. 1992. Effect of genotype and stocking density on post-weaning daily gain and meat production per hectare in cattle. Anim. Prod.: 65-72.

Miller, R.G., Jr. 1966. Simultaneous statistical inference. McGraw-Hill. N.Y.

Oswald, A.K. 1985. Impact and control of thistles in grassland, p 128136. In: Brockman, J.S. (ed.), Weeds, pests and diseases of grassland and herbage legumes. Brit. Grassl. Soc. Occasional Symp. No 18, British Crop Protection Council Monograph No 29. Univ. of Notthingham. UK.

Polley, H.W. and J.K. Detling. 1988. Herbivory tolerance of Agropyron smithii populations with different grazing histories. Oecologia 77:261-267.

Reuss, R.W., S.J. McNaughton, and M.B. Coughenour. 1983. The effect of clipping, nitrogen source and nitrogen concentration on the growth responses and nitrogen uptake of an East African sedge. Oecologia 59:253-261.

Ring, C.B., R.A. Nicholson, and J.L. Launchbaugh. 1985. Vegetational traits of patch-grazed rangeland in West-central Kansas. J. Range Manage. 38:51-55.

Shiyomi, M., T. Akiyama, and S. Takahashi. 1983. A spatial pattem model of plant biomass in grazing pasture. J. Japan Grassl. Sci. 28:373-382.

Steel, R.G.D. and J.H. Torrie. 1980. Principles and procedures of statistics. Mc.Graw Hill Book Co, N.Y.

Willms, W.D., J.F. Dormaar, and G.B. Schaalje. 1988. Stability of grazed patches on rough fescue grassland. J. Range Manage. 41:503-508. 